\title{
Initial growth and photosynthetic characteristics of Hymenaea courbaril plants submitted to different concentrations of potassium
}

\author{
Crescimento inicial e características fotossintéticas de plantas de Hymenaea courbaril \\ submetidas a diferentes concentrações de potássio
}

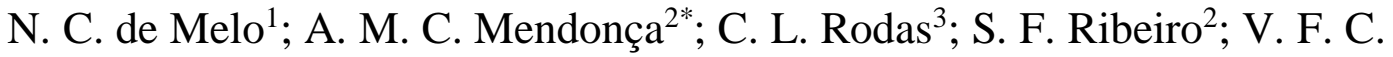 \\ Monteiro $^{2}$; J. P. R. A. D. Barbosa ${ }^{2}$ \\ ${ }^{1}$ Instituto Federal de Educação Ciência e Tecnologia do Pará, Avenida Almirante Barroso, $n^{o} 1155$, Bairro Marco, \\ CEP 66093-020, Belém- PA, Brasil \\ ${ }^{2}$ Universidade Federal de Lavras, Departamento de Biologia, Setor de Fisiologia Vegetal, Campus Universitário, \\ CEP 37200-000, Lavras-MG, Brasil. Caixa Postal 3037 \\ ${ }^{3}$ Universidade Federal de Lavras, Departamento de Ciências do Solo, Campus Universitário, CEP 37200-000, \\ Lavras-MG, Brasil. Caixa Postal 3037
}

*anemarcela@hotmail.com

(Recebido em 28 de julho de 2017; aceito em 26 de setembro de 2017)

\begin{abstract}
The degradation of Cerrado biome has been increasing the demand for high quality tree seedlings, so that it is necessary to understand the nutritional requirements of these plants. Hymenaea courbaril L., known as jatobá, has a wide distribution that makes it an alternative of reforestation of degraded areas. The aim of the experiment was to evaluate $H$. courbaril initial growth and gas exchange characteristics under different potassium concentrations $\left(\mathrm{K}^{+}\right)$. The experiment was arranged in a completely randomized design with five treatments (T0- 0, T1- 3, T2- 6, T3-9 e T4- 12 mM of $\mathrm{K}^{+}$) and four repetitions. Growth measurements were carried out every 15 days. SPAD index and gas exchange measurements were evaluated at 0,30 , and 60 days after treatment imposition. At the end of the experimental period, dry matter was evaluated, and root: shoot ratio (R:S) and Dickson quality index (DQI) were calculated The data were subjected to a one-way ANOVA and by Tukey's test $(\mathrm{P}<0.05)$. The growth characteristics did not show significant difference with different concentrations of $\mathrm{K}^{+}$. At 0 and 30 days the photosynthetic traits were not different. However, at 60 days the absent- (T0), lower- (T1), and hyper- $(\mathrm{T} 4) \mathrm{K}^{+}$concentration showed a reduction in SPAD index and gas exchanges parameters, confirming the role of this nutrient in the photosynthetic activity. Thus, regardless the $\mathrm{K}^{+}$doses during 60 days, $H$. courbaril reached the growth requirements of field plantations. However, after this period the plant survival could be decreased in low $\mathrm{K}^{+}$availability conditions.

Key words: Jatobá tree, hydroponic cultivation, reforestation.
\end{abstract}

A degradação do bioma Cerrado tem aumentado a demanda por mudas florestais de qualidade, sendo necessário entender os requerimentos nutricionais dessas plantas. Hymenaea courbaril L., conhecida como jatobá, tem ampla distribuição o que a torna uma opção para recuperação de áreas degradadas. O objetivo foi avaliar o crescimento inicial e as trocas gasosas de $H$. courbaril em diferentes concentrações de potássio $\left(\mathrm{K}^{+}\right)$. O experimento foi inteiramente casualizado com cinco tratamentos (T0- 0, T1- 3, T2- 6, T3- 9 e T4$12 \mathrm{mM}$ of $\mathrm{K}^{+}$) e quatro repetições. Quinzenalmente, medidas de crescimento foram realizadas. $\mathrm{O}$ índice SPAD e as trocas gasosas foram avaliados aos 0,30 e 60 dias após imposição dos tratamentos. Ao final do experimento, a massa seca total das plantas foi determinada e utilizada para calcular a razão raiz: parte aérea e o índice de qualidade de Dickson. Os dados foram submetidos à ANOVA e as médias comparadas pelo teste de Tukey $(\mathrm{P}<0.05)$. As características de crescimento não apresentaram diferenças em relação às concentrações de $\mathrm{K}^{+}$. Aos 0 e 30 dias, as trocas gasosas foram semelhantes. Entretanto, aos 60 dias, a ausência (T0), menor (T1) e hiper (T4) concentração de $\mathrm{K}^{+}$mostraram redução nos valores de índice SPAD e trocas gasosas, confirmando o papel desse nutriente na atividade fotossintética. Assim, independente da dose de $\mathrm{K}^{+}$durante 60 dias, $H$. courbaril alcançou o requerimento em crescimento para inserção em campo. Porém, períodos maiores que 60 dias podem reduzir a sobrevivência das mudas em baixa disponibilidade de $\mathrm{K}^{+}$.

Palavras-chave: Jatobá, cultivo hidropônico, reflorestamento. 


\section{INTRODUCTION}

The increased anthropogenic exploration of natural resources is causing disturbances in different biomes such as Cerrado (Brazilian savanna) [1]. The use of its original area by pasture and agricultural crops are turning this biome into a fragmented landscape with reduced diversity [2]. Thus, the recovery of the native vegetation demands an increase in the production of forest species seedlings, which is considered one of the most important steps toward to productive systems $[1,3]$.

However, the lack of information of forest seedlings production reduces the number of forest nurseries able to provide them $[4,5]$. When the seedlings are taken into the field conditions, they have to show the capacity to resist to the adversities until the moment they can compete with other species [4]. In this context, information related to nutritional aspects is important in order to improve the quality of forest plantations, guaranteeing the plant survival in adverse environments [6].

Among essential macronutrients, potassium $(\mathrm{K})$ is responsible for limiting plant growth and the productivity; its cation form $\left(\mathrm{K}^{+}\right)$is the most common in biochemical process as activator or cofactor enzyme [7]. It takes part in xylem and phloem long distance transport, regulates stomatal movements as well being involved in the photosynthesis and ATP synthesis [7, 8, 9]. Also, it has been shown an essential function by increasing plants resistance to abiotic and biotic stress $[10,11]$.

Hymenaea courbaril L., known as jatobá, belongs to Fabacaea family. It is a semideciduous, selective xerophytic, and heliophytic tree with a wide distribution [12, 13]. Interest in this plant has increased because of its adaptive behaviour. It is important to know about their nutritional requirements which can help seedlings production, and consequently, in reforestation programs [13]. As long as potassium may limit the initial plant establishment, we expect different growth and photosynthetic responses relative to different $\mathrm{K}+$ concentrations. Thus, in order to improve the production and survivor of native plants for reforestation, our study aimed to understand how variation of $\mathrm{K}^{+}$concentrations can affect the initial growth and photosynthetic characteristics of $H$. courbaril plants.

\section{MATERIALS AND METHODS}

Seeds of $H$. courbaril were obtained from trees located at the Federal University of Lavras,

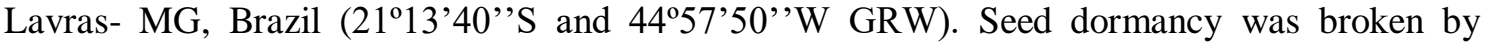
mechanical scarification and then sowed in plastic bags containing river-washed sand for emergency. After two months, plants with a pair of leaves were transferred to trays containing 36 $\mathrm{L}$ of nutritive solution for acclimation [14]; ionic strength was increased every seven days in a sequence of 25,50 and $100 \%$. At the end of the acclimation period, plants were transferred to plastic buckets with $6 \mathrm{~L}$ with constant aeration for treatment imposition.

The experimental design was a completely randomized composed by five treatments, which were represented by the change in potassium levels at Hoagland and Arnon (1950) [14] solution: 0 (T0- absent $\mathrm{K}^{+}$), 3 (T1- low $\mathrm{K}^{+}$), 6 (T2- normal), 9 (T3- high $\mathrm{K}^{+}$) and $12 \mathrm{mM}$ of $\mathrm{K}^{+}$(T4- hyper $\mathrm{K}^{+}$), with four replicates.

During the experimental period of 60 days, greenhouse temperature and air relative humidity were monitored by a termohigrometer (Extech Instruments, model RHT10) located one meter above ground level. The average temperature during experimental period was $22^{\circ} \mathrm{C}$, with a maximum of $29^{\circ} \mathrm{C}$ and the minimum of $16^{\circ} \mathrm{C}$. The average RH was $74 \%$, with a maximum of $84 \%$ and the minimum of $56 \%$.

Every 15 days, the shoot height $(\mathrm{cm})$, the stem diameter $(\mathrm{mm})$, the root height $(\mathrm{cm})$, and the number of leaves were measured. At the end of the experimental period, the plants were harvested and divided into the following compartments: leaves, stem, and roots, which were oven dried at $70^{\circ} \mathrm{C}$ for 48 hours. The dry weight was used to determine root: shoot ratio (R:S).

Biometric and allocation data were used to calculate Dickson Quality Index (DQI) [15], according to the Eq. 1: 
$\mathrm{DQI}=\mathrm{TDWx}\left[\left(\mathrm{HxD}^{-1}\right)+\left(\mathrm{SDWxRDW}^{-1}\right)\right]^{-1}$

where $T D W$ is the total dry weight, $H$ is the height, $D$ is the stem diameter, $S M$ is the shoot dry weight, and $R M$ is the root dry weight.

At 0,30 , and 60 days after treatment imposition SPAD index and gas exchange measurements were carried out. For SPAD index we used a portable chlorophyll meter $(a t L E A F+)$. The average of each treatment was a result of evaluations in four fully expanded leaves in each replicate.

Gas exchange was evaluated in the morning by an infrared gas analyzer (IRGA- model LI6400XT, Li-cor). The chamber was set with a photosynthetic photon flux density of $1000 \mu \mathrm{mol}$ $\mathrm{m}^{-2} \mathrm{~s}^{-1}$. Were determined net photosynthesis $\left(A-\mu \mathrm{mol} \mathrm{m} \mathrm{s}^{-2} \mathrm{~s}^{-1}\right)$, stomatal conductance $\left(g s-\mathrm{mol} \mathrm{m}{ }^{-}\right.$ $\left.{ }^{2} \mathrm{~s}^{-1}\right)$, and transpiration $\left(E-\mathrm{mmol} \mathrm{m} \mathrm{m}^{-2} \mathrm{~s}^{-1}\right)$. The water use efficiency $(W U E)$ was calculated by the $A / E$ ratio.

The data was subjected to a one-way ANOVA and, when needed, we applied Tukey as a pos hoc test $(\mathrm{P}<0.05)$ in SigmaPlot software (version 11.0) to compare average trait values among treatments in a same evaluation period or among evaluating periods.

\section{RESULTS AND DISCUSSION}

Variations in shoot height, stem diameter, root height, and number of leaves among the treatments with different $\mathrm{K}^{+}$concentrations were not significant, regardless the period of evaluation (Figure 1). According to Caldeira et al. (2008) [16], at the moment of transplantation, plants should have a shoot height between 30 and $35 \mathrm{~cm}$. Thus, independently of the $\mathrm{K}^{+}$treatment, all $H$. courbaril plants reached the required height to be transplanted to the field conditions, being the highest value of $35.5 \mathrm{~cm}$ observed in T2 (Figure 1a).
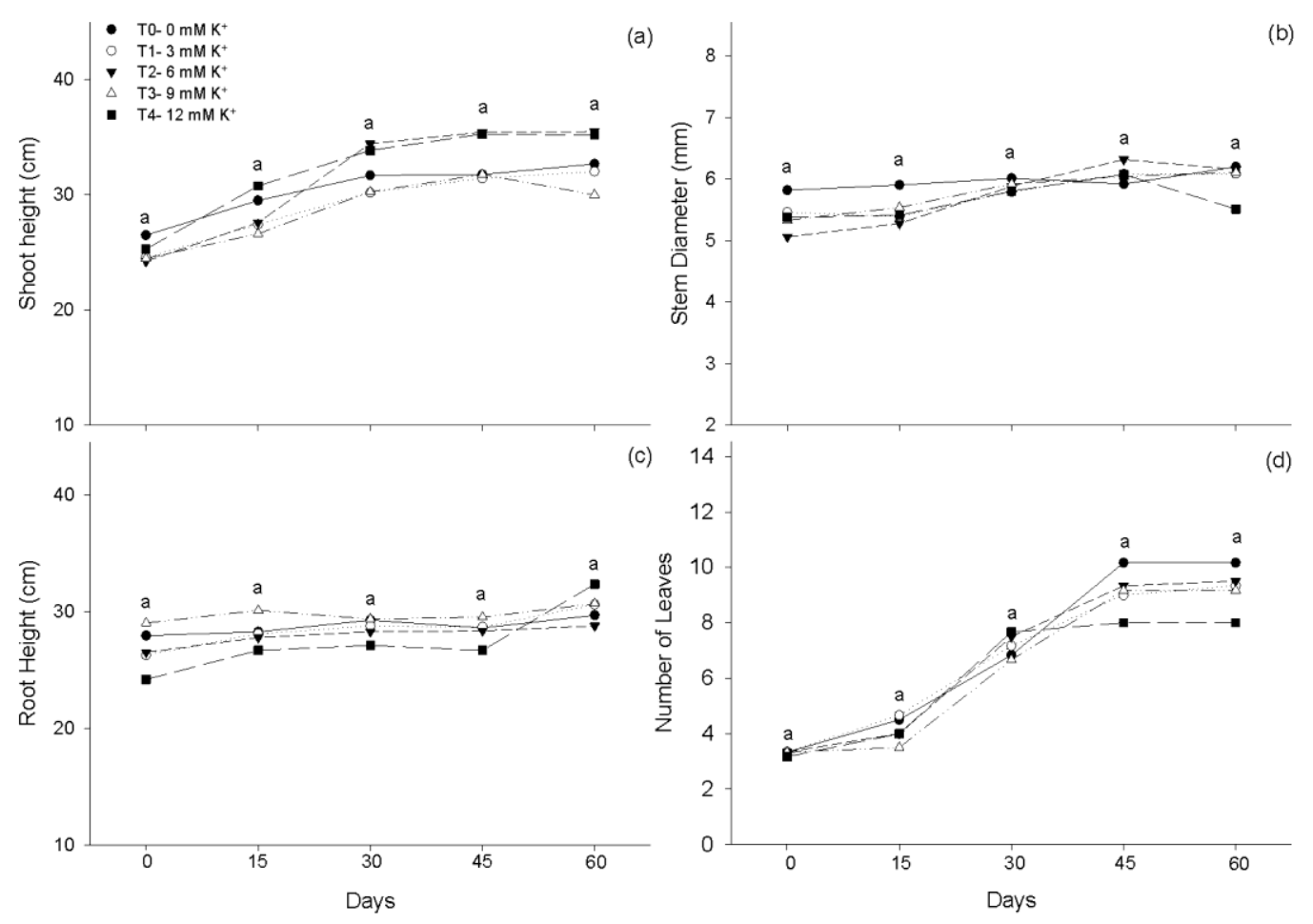

Figure 1: Shoot height (a), stem diameter (b), root height (c), and number of leaves (d) of Hymenaea courbaril plants in response to different potassium concentrations. Symbols represent average values $(n=4)$. Values followed by the same letters do not show significant differences in the same period of evaluation according to one-way ANOVA and Tukey post hoc test (P $\triangle 0.05)$. 
For Caryocar brasiliense plants, omission of $\mathrm{K}^{+}$did not affect the height, the stem diameter, and the total dry matter during the period of seedlings production which is related to the big size and rich nutrient composition of its seeds [6]. Considering that $H$. courbaril seeds are relatively big, it is possible that this characteristic may help plants cultivated in T0 to keep their growth despite of the absence of $\mathrm{K}^{+}$. Besides, all plants were acclimated in complete solution after treatment imposition which would have provide a post-emergent $\mathrm{K}^{+}$source that would equalize internal nutrient balance in all the samples. A similar result was observed for olive cultivar "Koroneiki" that did not show difference in shoot elongation in response to different $\mathrm{K}^{+}$ concentrations in hydroponic system [17]. Also, the supply with $10 \mathrm{mM}$ of $\mathrm{K}^{+}$did not reduce the growth in Jatropha curcas plants [18].

For R:S ratio, we did not observe significant differences among treatments. The highest average (0.23) was observed in T2 and T3 (Figure 2a). It is common that plants grown in a deficient $\mathrm{K}^{+}$medium rarely increase their root biomass [19]. On the other hand, studies have shown that the increase of $\mathrm{K}^{+}$concentration is responsible for decreasing biomass allocation into roots [10], although our results did not have this pattern. Experiment with olive plants demonstrates that they just modified their R:S biomass ratio in concentrations of $20 \mathrm{mM}$ [17], so that the maximum concentration used in $\mathrm{T} 4(12 \mathrm{mM})$ would be still low to invert biomass allocation pattern.
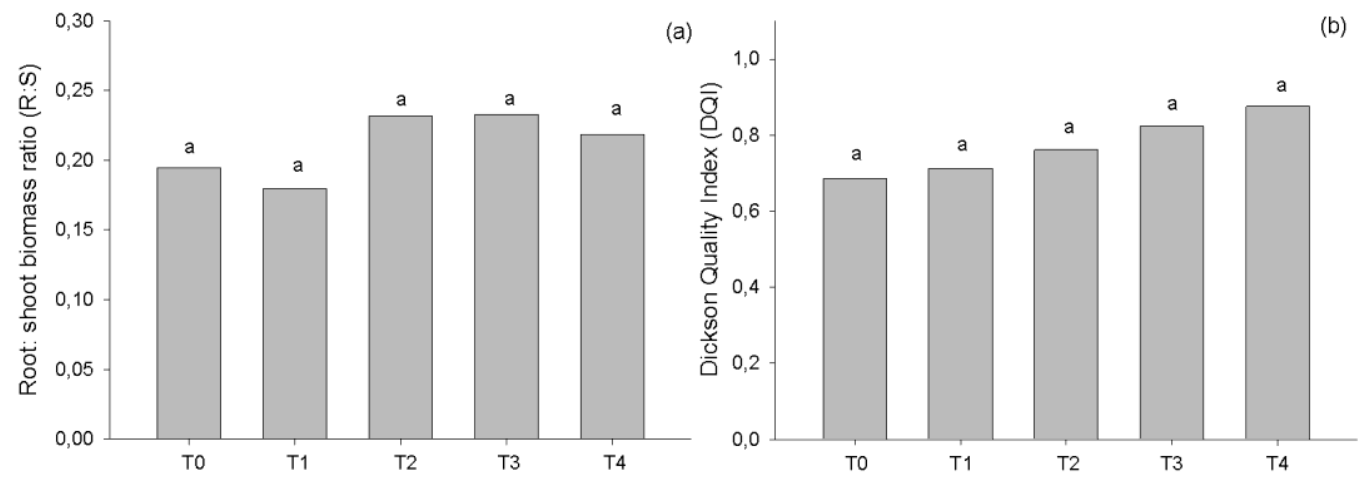

Figure 2: Root:shoot biomass ratio (a) and Dickson Index Quality (b) of Hymenaea courbaril plants in response to different potassium concentrations. Bars represent average values $(n=4)$. Values followed by the same letters do not show significant differences according to one-way ANOVA and Tukey post hoc test $(P \unlhd 0.05)$.

The DQI also did not show differences in spite of $\mathrm{K}^{+}$concentrations (Figure $2 \mathrm{~b}$ ). This index is considered an important indicator of plantlet quality, since the equilibrium of biomass distribution in the plant is taken into consideration. The results achieved were higher than the minimum 0.20 proposed by Silva et al. (2016) [20], which indicate that the different concentrations of $\mathrm{K}^{+}$did not cause the decrease of quality for $H$. courbaril plants analysed in the experimental conditions. Psidium guajava seedlings showed similar results, so that the different $\mathrm{K}^{+}$doses did not affect growth characteristic, including DQI [21].

Previous studies have indicated that forest species, including $H$. courbaril, are more affected by the omission of nutrients as nitrogen, phosphorous, and sulfur when compared to potassium [13]. Thus, besides the difference in $\mathrm{K}^{+}$concentration, the absence (T0), low (T1), high (T3) or hyper concentration (T4) of this nutrient did not prevent seedlings growth, result in visual symptoms of nutrient deficiency and excess or cause the death of $H$. courbaril plants.

The average values of SPAD index were not different at 0 and 30 days after treatment imposition. However, at 60 days, T2 and T3 showed higher values of 57.8 and 53.9 respectively, in comparison to the other treatments (Figure 3). 


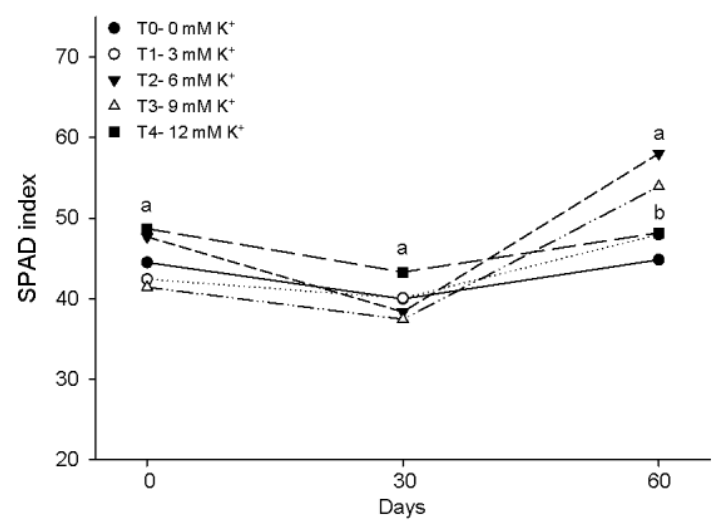

Figure 3: SPAD index of Hymenaea courbaril plants in response to different potassium concentrations. Symbols represent average values $(n=4)$. Values followed by the same letters do not show significant differences in the same day of evaluation according to one-way ANOVA and Tukey post hoc test (P $\leq 0.05)$.

For $A, g s, E$, and $W U E$ characteristics, significant differences at 0 and 30 days were not observed (Figure 4). Even if $\mathrm{K}^{+}$does not participate as a structural component in plants, it plays important roles in biochemical and physiological events, for instance the control of nitrogen utilization in chlorophyll production [22]. Thus, different $\mathrm{K}^{+}$doses did not affect the photosynthetic activity, as long as lower chlorophyll concentrations are not observed [11]. Since the concentrations of $\mathrm{K}^{+}$did not promote differences in SPAD index at 0 and 30 days, whereby total chlorophyll concentration can be assessed, plants could maintain their photosynthetic activity through the experimental period. Eucalyptus grandis plants did not have significant differences in $A$ and $g s$ after 30 days, either in deficient or excessive- $\mathrm{K}^{+}$treatments [23].
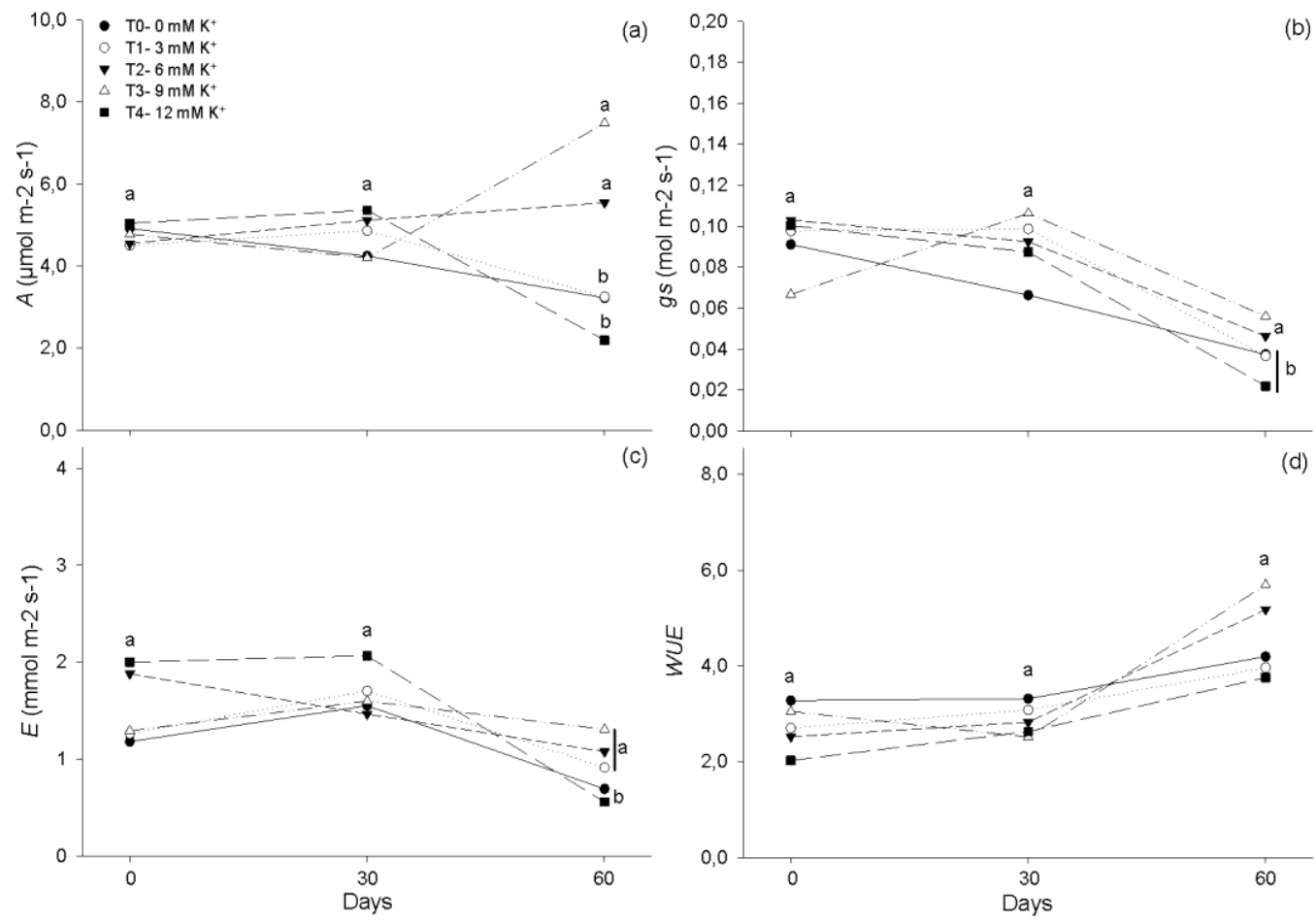

Figure 4: Net photosynthesis- A (a), stomatal conductance- gs (b), transpiration- E (c), and water use efficiency-WUE (d) of Hymenaea courbaril plants in response to different potassium concentrations. Symbols represent average values $(n=4)$. Values followed by the same letters do not show significant differences in the same day of evaluation according to one-way ANOVA and Tukey post hoc test $(P \triangle 0.05)$. 
At 60 days, there was no difference for WUE. On the other hand, higher values of $A$ (5.54 and $\left.7.50 \mu \mathrm{mol} \mathrm{m} \mathrm{s}^{-1}\right), g s\left(0.046\right.$ and $\left.0.056 \mathrm{~mol} \mathrm{~m}^{-2} \mathrm{~s}^{-1}\right)$, and $E\left(1.07\right.$ and $\left.1.30 \mathrm{mmol} \mathrm{m}^{-2} \mathrm{~s}^{-1}\right)$ were observed in T2 and T3, respectively (Figure 4). Potassium can maintain higher $g s$ and $E$ values as long as the plants are watered $[18,24]$. Carya cathayensis plants cultivated with $5 \mathrm{mM}$ of $\mathrm{K}^{+}$ showed higher carbon assimilation and chlorophyll content at 60 days which supports the idea of the role of $\mathrm{K}^{+}$in the photosynthetic traits [7].

However, treatments with lower SPAD index, which were absent- (T0), low- (T1), and hyper- $\mathrm{K}^{+}(\mathrm{T} 4)$, showed a reduction in gas exchange characteristics (Figure 3 and 4). It is argued that the main cause of the decrease in carbon assimilation in deficient- $\mathrm{K}^{+}$would be the increase in the mesophyll resistance or the decrease in the number of photosynthetic reaction centers [25]. In this way, it is possible that the decrease in SPAD index observed in T0 and T1 could have caused a decrease in the number of reaction centers (Figure 3). However, our results ensure the ones observed by Li et al. (2011) [26], which found that in a deficient- $\mathrm{K}^{+}$situation, the increase in stomatal resistance also plays a fundamental role in the reduction in $A$.

Also, our results indicate that hyper- $\mathrm{K}^{+}$dose (T4) causes decrease in the photosynthetic traits. The increase in $\mathrm{K}^{+}$concentration in the soil promotes the decrease in nitrogen concentration in the leaves [24]. Once nitrogen participates as a structural component in chlorophyll and Rubisco, it is possible that the increase in potassium dose could lead to a nitrogen deficiency and consequently a lower production of important molecules for photosynthesis process in natural environments. However, in hydroponic conditions we could not identify a decrease in the SPAD index associated with hyper- $\mathrm{K}^{+}$concentrations since this is such a neutral condition. This way we hypothesized that the observed photosynthetic patterns due to different $\mathrm{K}^{+}$concentration, especially at the end of the experimental period, could be related to stomatal miss control of leaf gas exchange.

There is a need for the utilization of an adequate $\mathrm{K}^{+}$concentration in order to reach a more efficient photosynthetic activity [8]. Our results suggest that for $H$. courbaril, the doses used in $\mathrm{T} 0, \mathrm{~T} 1$, and $\mathrm{T} 4$ started to cause a decrease in the $g_{s}, E$, and consequently in the net assimilation after 60 days. Therefore, plants cultivated in those conditions could have some irreversible damage and reduction in plant quality for field conditions if the period was longer than 60 days, with possible negative impacts in plant survival to field conditions after transplantation.

\section{CONCLUSION}

Growth characteristics, mainly height and DQI demonstrate through the experimental period that $H$. courbaril plants reach field requirements regardless the $\mathrm{K}^{+}$concentration. Thus, until 60 days, plants keep growing, this demonstrates their ability to insertion into field conditions. Nevertheless, at 60 days, our results show that the potassium absence (T0), low (T1), and hyper concentration (T4) start to cause a decrease in the gas exchange traits leading to decrease in leaf photosynthesis. It could lead to a reduction in plant survival in low $\mathrm{K}+$ availability conditions, as observed in some degraded areas, compromising reforestation activities.

\section{ACKNOWLEDGEMENT}

The authors would like to thank Coordenação de Aperfeiçoamento de Pessoal de Nível Superior (Capes) and Conselho Nacional de Desenvolvimento Científico e Tecnológico (CNPq) for scholarships concession.

\section{REFERENCES}

1. Lustosa-Filho JF, Nóbrega JCA, Nóbrega RSA, Dias BO, Amaral FHC, Amorim SPN. Influence of organic substrates on growth and nutrient contents of jatobá (Hymenaea stigonocarpa). Afr J Agric Res. 2015 June;10(26):2544-52, doi:10.5897/AJAR2015.9781 
2. Franco AC, Rossatto DR, Silva LCR, Ferreira CR. Cerrado vegetation and global change: the role of functional types, resource availability and disturbance in regulating plant community responses to rising $\mathrm{CO}_{2}$ levels and climate warming. Theor Exp Plant Physiol. 2014 Mar;26(1):19-38, doi:10.1007/s40626-014-0002-6

3. Oliveira DM, Caron BO, Elli EF, Monteiro GC, Schwerz F, Basso CJ, Manfron PA. Production and quality of Caesalpinia pluviosa seedlings in different substrates. Científica. 2017 Feb;45(1):1-8, doi:10.15361/1984-5529.2017v45n1p1-8

4. Lisboa AC, Santos PS, Oliveira Neto SN, Castro DN, Abreu AHM. Efeito do volume de tubetes na produção de mudas de Calophyllum brasiliense e Toona ciliata. Rev Árvore. 2012 Jul-Aug;36(4):6039, doi:10.1590/S0100-67622012000400003

5. Gonzaga LM, Silva SS, Campos AS, Ferreira RP, Campos ANR, Cunha ACMCM, Recipiente e substratos para a produção de mudas de jatobá (Hymenaea courbaril L.). Rev Bras Agropecu Sust. 2016 Mar;6(1):64-73, doi:10.21206/rbas.v6i1.309

6. Carlos L, Venturin N, Macedo RLG, Higashikawa EM, Garcia MB, Farias ES. Crescimento e nutrição mineral de mudas de pequi sob efeito da omissão de nutrientes. Ci Fl. 2014 Jan-Mar;24(1):13-21, doi: $10.5902 / 1980509813318$

7. Jin SH, Huang JQ, Li XQ, Zheng BS, Wu JS, Wang ZJ, Liu GH, Chen M. Effects of potassium supply on limitations of photosynthesis by mesophyll diffusion conductance in Carya cathayensis. Tree Physiol. 2011 Oct;31(10):1142-51, doi:10.1093/treephys/tpr095

8. Römheld V, Kirkby EA. Research on potassium in agriculture: needs and prospects. Plant Soil. 2010 Oct:335(1):155-80, doi:10.1007/s11104-010-0520-1

9. Wang M, Zheng Q, Shen Q, Guo S. The critical role of potassium in plant stress response. Int J Mol Sci. 2013 Apr;14(4):7370-90, doi:10.3390/ijms14047370

10. Santiago LS, Wright SJ, Harms KE, Yavitt JB, Korine C, Garcia MN, Turner BL. Tropical tree seedling growth responses to nitrogen, phosphorus and potassium addition. J Ecol. 2012 Mar;100(2):309-16, doi:10.1111/j.1365-2745.2011.01904.x

11. Zörb C, Senbayram M, Peiter E. Potassium in agriculture- status and perspectives. J Plant Physiol. 2014 May;171(9):656-69, doi:10.1016/j.jplph.2013.08.008

12. Carvalho PER. Espécies arbóreas brasileiras. Brasília: Embrapa Florestas; 2003. 1040p.

13. Nascimento HHC, Pacheco CM, Lima DRM, Silva EC, Nogueira RJMC. Aspectos ecofisiológicos de mudas de Hymenaea courbaril L. em resposta a supressão de N, P e K. Sci For. 2014 Sept;42(103):31528.

14. Hoagland D R, Arnon DI. The water culture method for growing plants without soil. Berkeley: California Agricultural Experimental Station; 1950. 32p.

15. Dickson A, Leaf A, Hosner JF. Quality appraisal of white spruce and white pine seedling stock in nurseries. For. Chron. 1960 Mar;36(1):10-3, doi:10.5558/tfc36010-1

16. Caldeira MVW, Blum H, Balbinot R, Lombardi KC. Uso de resíduo de algodão no substrato para produção de mudas florestais. Rev Acad Cienc Agrar. Ambient. 2008 Apr/Jun;6(2):191-202.

17. Saykhul A, Chatzistathisa T, Chatzissavvidisb C, Koundourasc S, Theriosa I, Dimassi K. Potassium utilization efficiency of three olive cultivars grown in a hydroponic system. Scr Hortic. 2013 Oct;162:55-62, doi:10.1016/j.scienta.2013.07.036

18. Rodrigues CRF, Silveira JAG, Viégas RA, Moura RM, Aragão RM, Silva EN. Combined effects of high relative humidity and $\mathrm{K}+$ supply mitigates damage caused by salt stress on growth, photosynthesis and ion homeostasis in $J$. curcas plants. Agric Water Manage. 2016 Jan;163:255-62, doi:10.1016/j.agwat.2015.09.027

19. Hermans C, Hammond JP, White PJ, Verbruggen N. How do plants respond to nutrient shortage by biomass allocation. Trends Plant Sci. 2006 Dec;11(12):610-7, doi:10.1016/j.tplants.2006.10.007

20. Silva MPS, Barroso DG, Souza JS, Ferreira DA, Oliveira TPF, Lamônica KR, Marinho CS.Growth and quality of australian cedar saplings originated from different multiclonal minigarden systems. Semin: Cien. Agrar. 2016 May/Jun;37(3):1127-34, doi:10.5433/1679-0359.2016v37n3p1127

21. Dias MJT, Souza HA, Natale W, Modesto VC, Rozane DE. Adubação com nitrogênio e potássio em mudas de goiabeira em viveiro comercial. Semin Cien Agrar. 2012 Nov/Dec;33(6):2837-48, doi:10.5433/1679-0359.2012v33Supl1p2837

22. Viana EM, Kiehl JC. Doses de nitrogênio e potássio no crescimento do trigo. Bragantia. 2010 Dec;69(4):975-82, doi:10.1590/S0006-87052010000400024

23. Battie-Laclau P, Laclau JP, Beri C, Mietton L, Muniz MRA, Arenque BC, Piccolo MC, Jordan-Meille L, Bouillet JP, Nouvellon Y. Photosynthetic and anatomical responses of Eucalyptus grandis leaves to potassium and sodium supply in a field experiment. Plant Cell Environ. 2014 Jan;37(1):70-81, doi:10.1111/pce.12131 
24. Perez BAP, Valeri SV, Cruz MCP, Vasconcelos RT. Potassium doses for African mahogany plants growth under two hydric conditions. Afr J Agric Res 2016 June;11(22):1973-79, doi:10.5897/AJAR2016.11026

25. Zhao D, Oosterhuis DM, Bednarz CW. Influence of potassium deficiency on photosynthesis, chlorophyll content, and chloroplast ultrastructure of cotton plants. Photosynthetica. 2001 Mar;39(1):103-9, doi:10.1023/A:1012404204910

26. Li XT, Cao P, Wang XG, Cao MJ, Yu HQ. Comparison of gas exchange and chlorophyll fluorescence of low-potassium-tolerant and -sensitive soybean [Glycine max (L.) Merr.] cultivars under lowpotassium condition. Photosynthetica. 2011 Dec;49(4):633-36, doi:10.1007/s11099-011-0073-4 